Berkala Ilmu Perpustakaan dan Informasi, Vol. 16, No. 1, Juni 2020, Hal. 55-67

DOI: 10.22146/bip.v16i1.171

ISSN 1693-7740 (Print), ISSN 2477-0361 (Online)

Tersedia online di https://journal.ugm.ac.id/v3/BIP

\title{
Perilaku pencarian informasi pekerjaan oleh sarjana fresh graduate dengan analisis Model Wilson
}

\author{
Nihayati ${ }^{1}$, Laksmi $^{2}$ \\ ${ }^{1,2}$ Department of Library and Information Sciency, Faculty of Humanities, \\ Universitas Indonesia, Kampus UI, Depok Indonesia 16424 \\ email :mailniha86@gmail.com; llaksmi706@gmail.com
}

Naskah diterima: 8 Maret 2020, direvisi: 30 Mei 2020, disetujui: 2 Juni 2020

\begin{abstract}
ABSTRAK
Pendahuluan Banyak sarjana fresh graduate yang masih mengalami berbagai hambatan dalam proses pencarian pekerjaan yang dibuktikan dengan makin tingginya tingkat pengangguran. Penelitian ini bertujuan untuk menganalisis faktor yang mempengaruhi perilaku pencarian informasi pekerjaan pada sarjana fresh graduate.

Metode Penelitian Metode penelitian menggunakan pendekatan kualitatif. Pengambilan sample dengan purposive sampling, jumlah responden 10 orang. Teknik pengambilan data menggunakan wawancara, yang dilakukan pada September-Oktober 2019.

Data Analisis Analisis data menggunakan teori Miles dan Huberman, yaitu reduksi data, penyajian data dan penarikan kesimpulan.

Hasil dan Pembahasan Hambatan pencarian informasi ditunjukkan dari faktor psikologis dan kemampuan interpersonal. Sarjana fresh graduate dengan keadaan psikologis dan kemampuan interpersonal rendah, seperti kurang percaya diri, bingung, minder, gelisah, kurang komunikasi hasil pencarian informasinya kurang memuaskan. Keadaan lingkungan pada 5 informan di perkotaan dengan sumber informasi melimpah dan kemudahan akses mendukung penemuan informasi pekerjaan yang lebih cepat, begitu pula sebaliknya.

Kesimpulan Penelitian ini menunjukkan bahwa perilaku pencarian informasi pekerjaan oleh 10 sarjana fresh graduate dikonstruksi oleh demografi, kemampuan interpersonal, dan lingkungan. Ketiga faktor dari lima variable intervening dalam konsep Wilson saling berhubungan dan membentuk pola yang berbeda berdasarkan kondisi lingkungan.
\end{abstract}

Kata kunci : pencarian informasi; sarjana fresh graduate; informasi pencarian kerja; model Wilson

\section{ABSTRACT}

Introduction. This paper discusses information seeking behavior of university fresh graduate. In fact, many university graduates still face serious difficulties in the job search process based on the increasingly high unemployment rate.

Data Collection Method. Purposive sampling was used with 10 respondents. Interviews were used as a data collection technique.

Data Analysis. Miles and Huberman data analysis was used in this study reduction, data presentation and conclusion..

Resultsand Discussions. Two barriers in finding information were from psychological factors and interpersonal abilities. New graduates with low psychological and interpersonal skills, such as lack of self-confidence, confusion, inferiority, anxiety, lack of communication show uneffective search results. The situation where information sources are easily accessible supports faster information retrieval and vice versa. Our five informants who lived in the city with easy access support the infomatation seeking process.

Conclusion Factors affecting information seeking behaviour were psychological situations, demographic circumstances, interpersonal abilities, environment and characteristics of information sources. Those five factors influence each other.

Keywords: information behaviour; information searching; fresh graduate; job seekers 


\section{A. PENDAHULUAN}

Perilaku informasi memusatkan pada kegiatan seseorang dalam mencari informasi. Perilaku informasi dimulai dari individu yang berada dalam situasi membutuhkan informasi. Kebutuhan informasi ini tidak secara langsung menjadi perilaku informasi, namun harus dipicu oleh suatu tekanan, masalah, maupun dorongan dalam kehidupannya. Salah satu kebutuhan informasi sarjana yang baru lulus (fresh graduate) adalah informasi pekerjaan. Informasi pekerjaan ini dapat diperoleh melalui media offline, seperti informasi dari teman/kerabat/saudara secara lisan, bursa kerja, lembaga perekrutan tenaga kerja, dalam surat kabar, dan melalui media online, misalnya internet, radio, televisi maupun berbagai platform sosial media. Saat ini sarjana perguruan tinggi yang baru lulus masih mengalami hambatan dalam proses pencarian pekerjaan, salah satu buktinya adalah makin tingginya tingkat pengangguran di level diploma dan sarjana.

Rilis dari Badan Pusat Statistik (Badan Pusat Statistik, 2019) pada Berita Resmi Statistik No 41/05/Th.XII, 06 Mei 2019 mengenai keadaan ketenagakerjaan di Indonesia menunjukkan bahwa angka pengangguran turun menjadi $5,01 \%$ atau berkurang sekitar 50.000 orang dalam satu tahun terakhir. Tingkat pengangguran terbuka (TPT) per Februari berjumlah 6,82 juta orang. Meskipun secara statistik angka pengangguran menurun, tetapi apabila dilihat dari tingkat pendidikan lulusan pengangguran tertinggi dari tingkat diploma dan sarjana. Lulusan diploma mengalami kenaikan pengangguran sebesar $8.5 \%$, sedangkan tingkat sarjana sebesar $25 \%$. Data tersebut menunjukkan kenaikan pengangguran di tingkat sarjana paling besar. BPS mengungkapkan bahwa salah satu penyebabnya adalah lulusan pendidikan rendah lebih menerima pekerjaan apapun, sedangkan di tingkat sarjana, mereka menunda bekerja sampai mendapat pekerjaan yang sesuai (Badan Pusat Statistik, 2019).

Untuk mendapatkan suatu pekerjaan, ada proses pencarian informasi pekerjaan. Pencarian informasi pekerjaan ini tidak serta merta mulus dan sama bagi setiap individu. Proses ini menemui berbagai hambatan, baik dari faktor personal seperti faktor psikologis maupun faktor eksternal, seperti keterbatasan akses informasi dan keadaan lingkungan (Susilo, 2018). Gordon, Meindl, White dan Szigeti (2018) meneliti perilaku pencarian informasi kalangan kimiawan, hasilnya 13,9 \% mengakui bahwa mereka berhasil mengikuti perkembangan terbaru, sementara $50,6 \%$ persen menunjukkan bahwa mereka berhasil, tetapi sebesar 35,5 \% tidak berhasil. Adapun hambatannya adalah (1) terlalu banyaknya informasi, menghabiskan banyak waktu; (2) sebagian besar kimiawan tidak yakin dengan nilai dan kredibilitas paten; dan (3) kimiawan terus terbuka terhadap perkembangan teknologi dan sumber daya baru. Titus (2016) melihat bahwa implikasi sosial media memudahkan proses difusi informasi pekerjaan, tetapi ada beberapa temuan masalah yang disampaikan oleh responden, antara lain perekrutan dan organisasi tidak memberikan tanggapan mengenai status aplikasi mereka, email penolakan atau kadang tidak aktif, mengurangi tingkat keterlibatan penyedia pekerjaan dalam proses rekrutmen terjadi di seluruh platform media sosial.

Al-Samarraie, Eldenfria \& Dawoud (2017) meneliti personality trait (kepribadian) dalam pencarian informasi, dengan membaginya menjadi tiga klaster, yaitu klaster pertama terdiri dari peserta yang mendapat skor tinggi dalam conscientiousness (sifat berhati-hati); klaster dua dalam agreeableness (mudah bersepakat); dan klaster tiga tinggi dalam extraversion (ekstraversi atau tingkat kenyamanan dalam berinteraksi). Hasil penelitian menunjukkan bahwa individu yang memiliki trait conscientiousness akan melakukan sebagian besar tugas pencarian informasinya dalam waktu paling cepat, diikuti oleh orang-orang yang memiliki sifat agreeableness tinggi, baru kemudian individu yang memiliki sifat extraversion. Sementara A. Dinia (2016) melihat hubungan antara trait conscientiounusness dengan perilaku pencarian informasi dengan teori Job Behaviour Scale oleh Hooft dkk (2004) dan The Big Five 
Personality oleh Golberg (1992) dan hasil keduanya memiliki hubungan positif cukup signifikan $(\mathrm{r}=0,190, \mathrm{p}<0,01)$ serta memiliki pengaruh positif $(\beta=0,191, p=0,000)$ terhadap perilaku pencarian kerja pada sarjana baru perguruan tinggi.

Perilaku mencari informasi paling berpengaruh ketika didorong oleh motivasi intrinsik, sedangkan perilaku eksrinsik sifatnya hanya melengkapi. Motivasi seseorang untuk mencari informasi dipengaruhi oleh keyakinan individu terkait dengan motivasi intrinsik, nilai pencapaian, nilai utilitas, kontak dengan kerabat, serta biaya pencarian informasi (Savolainen, 2018). Faktor personal seperti selfesteem juga turut mempengaruhi perilaku pencarian kerja yang dikaitkan dengan keterampilan sosial dan inisiatif individu. Individu dengan self-esteem yang tinggi menampilkan keterampilan sosial yang kuat seperti menanyakan informasi kepada seluruh kolega dan inisiatifmencari informasi pekerjaan dari berbagai sumber (Amalina, 2016). Niat diri individu juga berperan dalam pencarian informasi terkait jurnalisme untuk melakukan tugas penyalinan salinan, persiapan wawancara, tugas menghubungkan data dan tugas cerita lapangan. Pola reguler dalam niat ini dapat dieksploitasi untuk identifikasi jenis tugas dan juga potensi aplikasi untuk personalisasi dan rekomendasi selama periode waktu pencarian informasi (Mitsui, Shah, \& Belkin, 2016). Pengalaman penggunaan internet juga memberikan pengaruh kuat kepada pengguna, kualitas sumber informasi dan pada akhirnya mempengaruhi niat/keyakinan dalam mencari informasi (Fetherston, 2017).

Wilson (1999) mengungkapkan bahwa perilaku informasi merupakan siklus melingkar yang berkaitan dengan pengolahan dan pemanfaatan informasi dalam kehidupan seseorang. Proses mewujudkan kebutuhan informasi ke dalam bentuk perilaku informasi dipengaruhi oleh beberapa hal, yaitu kondisi psikologis seseorang, keadaan demografis, peran seseorang di dalam masyarakat, lingkungan dan karakteristik sumber informasi. Hasil penelitian sebelumnya masih berkutat pada proses pencarian informasi dan faktor- faktor yang mempengaruhi perilaku pencarian informasi. Oleh karena itu peneliti tertarik untuk melakukan penelitian terkait dengan perilaku sarjana perguruan tinggi dalam pencarian informasi pekerjaan dalam konteks yang holistik, mulai kebutuhan informasinya, pemicu kebutuhan informasi kondisi psikologis, keadaan demografis, interpersonal, lingkungan dan karakteristik sumber informasi dan bagaimana keterkaitan antara konteks dalam pencarian informasi. Penelitian ini bertujuan untuk mengidentifikasi bagaimana faktor-faktor tersebut mempengaruhi perilaku informasi sarjana fresh graduate dan bagaimana keterkaitan antara faktor-faktor tersebut. Hasil penelitian ini diharapkan dapat memberikan kontribusi dalam pengembangan konsep perilaku pencarian informasi dan pelayanan informasi.

\section{B. TINJAUAN PUSTAKA}

Penelitian terkait perilaku informasi dalam pencarian kerja yang dilakukan oleh Mowbray, Hall, Raeside, dan Robertson (2018) bertujuan untuk mengetahui perilaku pencari kerja kategori usia muda yang mengadopsi pendekatan jaringan egosentris. Jenis penelitian adalah kualitatif dengan metode pengambilan data melalui wawancara semi struktur. Data kemudian dianalisis dengan teori kebutuhan informasi dan pencarian informasi Wilson (1981). Hasil penelitian menunjukkan bahwa pencari kerja memperoleh berbagai informasi pencarian kerja dari kontak di jaringan sosial media mereka. Ternyata, kontribusi kontak dari jaringan tersebut melebihi dari sekedar berbagi informasi lowongan pekerjaan. Selain pencarian informasi melalui platform sosial media, mereka juga mengadopsi informasi langsung dari kontak industri yang membuka lowongan. Hal ini memberikan peluang informasi yang sangat berharga bagi pencari kerja. Hasil penelitian ini merekomendasikan pemahaman yang lebih luas tentang perilaku informasi yang mendukung mobilisasi kontak yang efektif dalam jejaringan sosial selama pencarian kerja.

Di Indonesia, penelitian mengenai perilaku informasi dalam pencarian kerja telah dilakukan 
oleh Susilo (2018) untuk mengetahui perilaku sarjana fresh graduate dalam menemukan informasi lowongan kerja dan hambatannya. Penelitian menggunakan pendekatan deskriptif kuantitatif dengan jumlah responden 101 orang. Peneliti menggunakan model dari Meho dan Tibbo yang merupakan perluasan dari teori Ellis untuk menganalisis perilaku informasi. Hasil penelitian menunjukkan bahwa sarjana fresh graduate melakukan proses penemuan informasi lowongan pekerjaan dengan cara-cara tertentu pada setiap tahapannya dan disertai alasan-alasan tertentu. Selain itu, temuan penelitian menunjukkan bahwa dalam proses penemuan lowongan kerja, para responden menemui berbagai hambatan, di antaranya bingung/gelisah/bimbang, kesulitan dalam menemukan kata kunci yang diinginkan, kesulitan memahami pembicaraan atau bahasa, dana terbatas untuk mengakses informasi secara online dan konten informasi lowongan kerja yang tidak lengkap. Pencarian informasi merupakan kegiatan yang disengaja sebagai konsekuensi dari kebutuhan informasi.

Case (2016) mengidentifikasi pencarian informasi sebagai perilaku yang muncul ketika sesorang merasa dalam permasalahan atau ada kesenjangan informasi dalam pengetahuan, keyakinan, dan lingkungannya yang tidak menunjukkan jalan untuk mencapai tujuan kepuasannya. Ada beberapa tokoh dalam displin ilmu informasi, di antaranya Wilson, Ellis, dan Kuhlthau yang mengemukakan teorinya masing-masing mengenai perilaku pencarian informasi. Teori dari ketiga tokoh ini dapat dimanfaatkan sebagai acuan dalam membuat kajian pemakai di perpustakaan (Widiyastuti, 2016).

Wilson (1984) menyatakan bahwa pendekatan kognitif dalam perilaku informasi berpusat pada gagasan tentang makna. Pendekatan tersebut tidak hanya melibatkan aspek dalam produksi informasi, transfer informasi, dan penggunaan informasi; tetapi juga cara individu-individu mendefinisikan diri mereka sendiri, kehidupan, maupun tindakan mereka. Oleh karena itu, perlu adanya jembatan antara makna kehidupan sehari-hari dan informasi. Perilaku informasi merupakan siklus melingkar yang berkaitan dengan pengolahan dan pemanfaatan informasi dalam kehidupan seseorang. Lebih lanjut Wilson (1999) merevisi model perilaku informasi pada Gambar 1 .

Gambar 1 menunjukkan bahwa kebutuhan informasi tidak akan langsung menjadi perilaku informasi tetapi melalui proses yang bertahap. Perilaku informasi dimulai dari:

1. Keadaan dimana individu yang membutuhkan informasi dalam konteksnya sampai pada pengolahan dan pemanfaatan informasi. Konteks sangat bervareasi di setiap masyarakat, namun berlaku universal. Konteks kebutuhan informasi individu berkaitan erat dengan faktor fisiologis, afektif, dan kognitif. Faktor fisiologis yaitu kebutuhan makan, tempat tinggal, dan lain-lain. Faktor afektif kadang disebut sebagai kebutuhan psikologis atau emosional, yaitu kebutuhan untuk pencapaian, kekuasaan, dan lain-lain. Faktor kognitif terkait dengan kebutuhan untuk menambah pengetahuan dan informasi (Laksmi, 2016).

2. Mekanisme pengaktifan pertama menurut Case (2016) yaitu aktifitas pemicu dalam pencarian informasi. Aktivitas ini berkaitan dengan bentuk perilaku dan pikiran individu dalam mengurangi kondisi yang dapat menimbulkan stress dalam melakukan pencarian informasi. Ia dapat mengatur emosinya, berhati-hati, atau bahkan menghindari permasalahan.

3. Kemudian pada tahap selanjutnya kebutuhan informasi berubah menjadi aktivitas mencari informasi, ada beberapa hal yang mempengaruhi perilaku tersebut. Faktor-faktor-yang mempengaruhi perilaku tersebut adalah kondisi psikologis seseorang, demografis, peran seseorang dalam masyarakat, lingkungan dan karakteristik sumber daya informasi.

4. Mekanisme aktivasi kedua, yaitu aktivitas seseorang dalam melakukan pencarian informasi, yaitu bagaimana dan sampai sejauh mana proses pencarian informasinya serta pandangan terhadap risiko dan imbalan yang akan diperoleh. Risikoberupa hambatan yang dihadapi, misalnya waktu, 
biaya, dan kemudahan akses.

5. Tahap selanjutnya adalah pencarian informasi. Ada empat perilaku pencarian informasi, yaitu perhatian pasif, pencarian pasif, pencarian aktif dan pencarian berlanjut. Perhatian pasif, yiatu penemuan yang informasi yang tidak disengaja. Pencarian pasif adalah pencarian yang kebetulan sesuai dengan kebutuhan informasi individu. Pencarian aktif terjadi ketika individu secara aktif mencari informasi. Pencarian berlanjut dilakukan oleh individu apabila kebutuhan informasinya belum terpenuhi.

6. Tahap terakhir, yaitu pengolahan dan pemanfaatan informasi. Individu yang memperoleh informasi akan menganalisisnya, menyimpan, mendistribusikan atau mengolah dengan cara lain. Setelah itu informasi dimanfaatkan sesuai kebutuhan informasi berdasarkan konteks saat itu (Laksmi, 2016).

Dari penjelasan di atas, perilaku informasi merupakan keseluruhan tingkah laku manusia dalam kaitannya dengan keterlibatan informasi, mulai dari sadar akan kebutuhan informasi kemudian memikirkan, mencari sampai memanfaatkan berbagai sumber informasi.

Perilaku informasi sebenarnya dipengaruhi oleh lapisan informasi yang berbeda. Secara khusus, personalisasi pencarian pengguna menggunakan informasi yang tersedia dari web sosial dapat menjadi keuntungan bagi pengguna, seperti peningkatan rating, seleksi informasi, dan mengurangi konsultasi eksternal. Selain itu, efektivitas lapisan sosial dan pribadi juga berpengaruh dalam perilaku informasi. Meskipun ditemukan perubahan signifikan dalam kinerja pencarian informasi, namun kebanyakan tidak menyadari perbedaan dalam individu itu sendiri (Orso, Ruotsalo, Leino, Gamberini, \& Jacucci, 2017). Suatu disiplin ilmu tidak mempengaruhi perilaku pencarian informasi, tetapi ada variabel lain, yaitu pengalaman pencarian informasi, softskill, keterampilan komputer atau website dan frekuensi penggunaan sumber informasi memainkan peran penting dalam membentuk perilaku pencarian informasi (Korobili, Malliari, \& Zapounidou, 2011). Efektivitas perilaku pencarian kerja ditentukan oleh aktivitas pencarian spesifik, intensitas pencarian informasi, kualitas perilaku pencarian inforamsi, serta perubahan aktivitas pencarian informasi (Van Hoye, 2017).

Ada hubungan saling ketergantungan antara kontekstual yang lebih luas dari faktor lingkungan digital dan tingkat informasi pengguna dalam perilaku pencarian informasi. Temuan menunjukkan bahwa ada perbedaan jenis persyaratan dan konteks dalam berbagai jenis informasi, substansi informasi, dan niat/keyakinan dalam diri individu saat menyelesaikan suatu tugas informasi (Vuong, Saastamoinen, Jacucci, \& Ruotsalo, 2019). Perspektif perilaku informasi menurut Lueg (2015) terkait dengan individualitas dalam perilaku informasi alias gaya informasi atau perilaku informasi dianggap sebagai praktik sosial karena bergantung pada faktor secara fisik manusia itu sendiri. Perspektif perilaku informasi merupakan salah satu langkah untuk mengangkat ilmu sosial dalam kognitif ilmu pengetahuan. Penelitian perilaku informasi ini menjadi diskusi menarik lintas batas-batas disiplin ilmu.

\section{METODOLOGI PENELITIAN}

Penelitian ini menggunakan pendekatan kualitatif. Penelitian kualitatif bertujuan untuk mendalami fenomena apa yang dialami oleh subjek penelitian dengan memanfaatkan metode ilmiah, kemudian dideskripsikan dalam bentuk kata-kata dan Bahasa (Moleong, 2017). Pengambilan sampel dengan metode purposive sampling, yaitu teknik pengambilan sampel sumber data dengan pertimbangan tertentu (Sugiyono, 2016). Kriteria informan dalam pengambilan sampel ini adalah (1) informan sarjana fresh graduate dengan masa lulus maksimal satu tahun, (2) informan dari daerah yang berbeda (3) informan dari universitas yang berbeda, dan (4) informan yang baru mencari informasi pekerjaan atau sudah mencari informasi pekerjaan. Penelitian dilakukan pada bulan September - Oktober 2019. Informan dalam penelitian ini berjumlah 10 orang. Teknik 
pengambilan data menggunakan wawancara. Wawancara dilakukan secara langsung bagi informan di daerah yang dijangkau peneliti, sementara bagi informan yang tidak terjangkau peneliti dilakukan melalui telepon dan chat melalui aplikasi WA. Data yang terkumpul kemudian dianalisis dengan model perilaku informasi Wilson dan teori pendukung terkait. Analisis data dalam penelitian ini menggunakan analisis interaktif (interactive models of analysis) Miles dan Huberman (2014) yang terdiri dari reduksi data, penyajian data dan penarikan kesimpulan.

\section{HASILDAN PEMBAHASAN}

Informan penelitian ini berjumlah 10 orang dengan kriteria utama adalah sarjana fresh graduate masa lulus maksimal satu tahun. Tabel 1 mengenai sebaran data umum informan.

Kesepuluh informan secara umum berasal dari daerah yang berbeda-beda dan program studi yang berbeda. Informan terdiri dari 7 perempuan dan 3 laki-laki dengan rentang usia 21 tahun sampai 23 tahun. Dari kesepuluh informan tersebut, 6 informan sudah berhasil melakukan pencarian pekerjaan dan sudah bekerja; sedangkan 4 informan lainnya masih dalam proses pencarian informasi pekerjaan.

Berdasarkan hasil wawancara, area tempat tinggal meliputi area kampung/pedesaam, perumahan atau kompleks, dan tinggal di kos. Pekerjaan di lingkungan sekitar responden beraneka ragam. Di daerah pedesaan mayoritas pekerjaan di lingkungannya adalah petani dan wiraswasta, sedangkan di perkotaan mayoritas pekerjaan adalah pengusaha dan PNS. Media yang digunakan informan untuk mencari informasi pekerjaan melalui offline, yaitu informasi dari teman atau kerabat, bursa kerja dan melalui informasi online, yaitu sosial media faceebook, instagram dan website jobstreet. Perguruan tinggi asal dari ke sepuluh informan juga berbeda.

\section{Perilaku Sarjana Fresh Graduate dalam Pencarian Informasi Pekerjaan Konteks kebutuhan informasi}

Pada konteks kebutuhan informasi, seseorang sudah memiliki pemikiran awal atau gambaran mengenai informasiyang melibatkan aspek kognitif, aspek afektif, dan peran sosial. Sarjana fresh graduate tentunya sudah memiliki gambaran, akan melanjutkan pendidikan ke jenjang pascasarjana ataukah akan bekerja. Apabila ingin mencari melanjutkan pendidikan tentunya akan mencari informasi mengenai minat program pascasarjana, universitas, biaya perkuliahan, dan lain-lain. Begitu halnya apabila hendak bekerja, maka dia akan mencari informasi terkait pekerjaan.

Konteks kebutuhan informasi sangat bervareasi di setiap masyarakat, namun berlaku universal (Laksmi, 2016). tujuh dari informan (bergender perempuan) mengungkapkan bahwa konteks kebutuhan pencarian informasi adalah untuk "ya.yang jelas memperoleh penghasilan dan memenuhi kebutuhan hidup mbak.. " Dalam konteks fisiologis, kebutuhan informasi pekerjaan oleh informan antara lain untuk memperoleh penghasilan guna memenuhi kebutuhan hidup. Anto mengatakan bahwa kebutuhan pencarian informasi adalah, "..kalau saya sih meningkatkan derajat orang tua mba..", sementara Karto menjawab.."saya ingin hidup mandiri, tidak bergantung pada orangtua lagi.." dan Ipul mengatakan.." ingin kaya mbak, hehe. "Kebutuhan afektif dari ketiga informan tersebut antara lain meningkatkan derajat orang tua, belajar hidup mandiri, dan menjadi kaya.

Kelima dari 10 informan, yaitu Wati, Tuti, Jihan, Anik dan Anto menambahkan kebutuhan informasi pekerjaan adalah untuk menumbuhkan skill pribadi, mencari pengalaman dan pengetahuan baru, serta berbagi pengetahuan dengan orang lain. Kebutuhan informasi ini masuk dalam kategori kebutuhan kognitif. Sementara kebutuhan informasi terkait peran sosial sarjana fresh graduate yaitu melanjutkan pendidikan pascasarjana atau mencari pekerjaan. Jadi, temuan penelitian ini memperlihatkan bahwa 
kebutuhan informasi pekerjaan sarjana fresh graduate terdiri dari konteks fisiologis, afektif, kognitif, dan peran sosial.

\section{Pemicu Pencarian Informasi Pekerjaan}

Aktivitas ini berkaitan dengan cara memperoleh informasi untuk memecahkan persoalan dengan didorong motivasi yang kuat. Pada tahap ini faktor psikologis sangat berperan dalam diri seseorang. Perilaku mencari informasi paling berpengaruh ketika didorong oleh motivasi intrinsik, sedangkan perilaku ektsrinsik sifatnya melengkapi (Savolainen, 2018). Pencarian informasi pekerjaan oleh sarjana fresh graduate didorong oleh motivasi dalam diri informan selain memperoleh penghasilan dan membahagiakan orang tua ada temuan ekstrinsik yang menarik, yaitu anggapan sosial mengenai pekerjaan lulusan sarjana. Seperti yang diungkapkan Tuti dan Ika .." banyak tetangga atau masyarakat berpikiran lebih jauh ketika seseorang lulusan sarjana harusnya mendapat pekerjaan yang lebih baik, kerja ga pake fisik, jadi PNS yang dijunjung tinggi di desa kami..”. Anggapan sosial masyarakat yaitu lulusan sarjana harusnya mendapat pekerjaan yang bagus, yang gajinya lebih besar dan tidak menggunakan tenaga fisik. Bahkan di daerah pedesaan ada anggapan bahwa menjadi PNS adalah pekerjaan yang paling baik. Tentu hal ini juga turut memotivasi individu dalam melakukan pencarian informasi pekerjaan.

Dalam hal identifikasi motivasi mendapatkan penghasilan, ada temuan unik yaitu motivasi Desi dalam mencari informasi pekerjaan, yaitu apabila mendapatkan pekerjaan maka dia dapat memenuhi keinginannya melakukan perawatan wajah (skincare). Saat sekolah sampai kuliah keinginan tersebut belum terlaksana karena tidak ingin membebani orangtua. Pemicu pencarian informasi pekerjaan oleh sarjana fresh graduate berasal dari hasrat psikologis individu dan tekanan sosial. Temuan dalam penelitian ini memperlihatkan bahwa pemicu pencarian informasi pekerjaan adalah keyakinan mendapatkan pekerjaan, memenuhi kebutuuhan sampai menjadi kaya. Keyakinan sarjana akan mendapatkan pekerjaan lebih baik (misalnya sebagai PNS). Keyakinan tersebut membangun perilaku pencarian infofmasi lowongan pekerjaan khusus penerimaan PNS. Keyakinan memperoleh pekerjaan lebih baik, dengan harapan nanti akan menjadi kaya.

\section{Pengaruh Psikologi Sarjana Fresh graduate dalam Mencari Informasi Pekerjaan}

Faktor psikologi mempengaruhi perilaku pencarian informasi (Wilson, 1999). Pemicu pencarian informasi pekerjaan sarjana fresh graduate dalam penelitian ini berasal dari hasrat psikologis individu, yaitu keinginan untuk memperoleh penghasilan dan membahagiakan orang tua, dan tekanan sosial, yaitu setelah lulus bebannya semakin berat mencari pekerjaan yang sesuai, apalagi sarjana setidaknya mendapat pekerjaan yang lebih bagus. Dari pemicu tersebut kemudian muncul berbagai perasaan yang berbeda saat melakukan pencarian informasi.

Saat individu berada pada kondisi psikologis yang berbeda, seperti bingung, kurang percaya diri, atau cemas maka mereka akan menunjukkan perilaku infomasi yang berbeda dibandingkan dengan individu yang senang dan percaya diri saat dalam melakukan pencarian. Wati, Jihan, Ita dan Anik mengatakan kurang percaya diri, ragu dan merasa bingung saat mencari informasi. Sementara Desi, Karto dan Ipul bersemangat dan percaya diri. Hasil penelitian ini memperlihatkan bahwa saat informan merasa kurang percaya diri, bingung, ragu, gelisah yaitu merasa informasi pekerjaan yang diperoleh di atas kemampuannya, seperti yang diungkapkan Anto "ini nanti saya kayaknya ga lolos, ini pasti banyak saingannya, ini di atas kemampuan saya, ini nanti ke depannya gimana ya bagus ga ya, dan sebagainya." Mereka lalu melakukan pencarian lagi, tetapi masih ragu sehingga belum menemukan, kemudian mencari lagi, begitu seterusnya. Dalam proses ini, pada dasarnya informan sudah melakukan pencarian aktif bahkan sampai pencarian tingkat lanjut, akan tetapi karena berbagai perasaan negatif tersebut hasil yang diperoleh tidak maksimal, tidak sesuai ekspektasi, tidak memuaskan bahkan ada 
informan yang hampir satu tahun belum menemukan informasi pekerjaan yang pas.

Hasil penelitian memperlihatkan bahwa informan yang semangat dan penuh percaya diri pada saat melakukan pencarian informasi, mereka dengan sigap menganalisis setiap informasi yang diperoleh, menyesuaikan dengan kualifikasi dan kemampuannya, seperti yang dilakukan oleh Karto, Desi dan Indar. Pada proses pencarian ini, informan berada dalam pencarian aktif, dengan perasaan positif hasil pencairan informasi yang diperoleh memuaskan dan memenuhi ekspektasi. Hal ini menunjukkan bahwa dalam keadaan psikologis yang berbeda, perilaku informasinya pun berbeda. Oleh karena itu, faktor psikologis mempengaruhi perilaku pencarian informasi. Perilaku pencarian informasi juga dipengaruhi oleh faktor stress (coping). Coping merupakan perilaku yang dilakukan seseorang untuk mengurangi atau menghilangkan ketegangan, seperti tekanan pada situasi kehidupan. Untuk mengatasi hambatan psikologis (coping) ini ada beberapa kegiatan yang dilakukan informan, antara lain berbagi informasi dengan kerabat dan teman, main game, refreshing, refleksi diri jalan-jalan dan berdoa kepada Tuhan.

\section{Faktor Demografi Sarjana Fresh graduate dalam Mencari Informasi Pekerjaan}

Wilson (1999) mengatakan bahwa faktor demografi mempengaruhi perilaku pencarian informasi. Demografi meliputi keadaan sosial budaya sebagai bagian dari tempat individu hidup dan beraktivitas. Sarjana fresh graduate yang tinggal di daerah pedesaan jauh dari pusat kota, memiliki akses internet yang kurang kuat. Saat melakukan pencarian infomasi secara online, mereka harus ke pusat kota atau mengunjungi warnet. Hal tersebut sangat menyita banyak waktu. Ketersediaan informasi di daerah pedesaan informan juga kurang berlimpah seperti halnya di kota karena keterbatasan media akses. Selain itu mereka membutuhkan biaya untuk sewa warnet atau membeli paket data. Hambatan demografi ini ternyata memunculkan hambatan waktu dan biaya.
Di daerah Ngawi, Pati, Sleman dan Jambi masih kental dengan tradisi lisan, informasi pekerjaan yang diperoleh pun sebagian besar berasal dari informasi sahabat, tetangga dan kerabat. Perilaku fresh graduate kategori ini menggali informasi pekerjaan tentang keakuratan informasi, bagaimana cara melamar, maupun keadaan di tempat kerja secara offline dengan mengunjungi sumber informasi langsung dan sekaligus sebagai ajang silaturahmi. Seperti yang dikatakan Tuti, .."di daerah saya (Ngawi) masih berbagi informasi secara lisan atau dari mulut ke mulut, kita berkunjung ke sumber informasi,sekalian silatuhrami dan menanyakan kebenaran, syaratnya sampe kondisi lingkungan kerja.." Unsur budaya silaturahmi turut berperan dalam pencarian informasi. Perilaku informasi fresh graduate yang tinggal di daerah perkotaan dengan akses internet kuat cenderung mencari informasi secara online. Pada saat mencari informasi pekerjaan, mereka menyaring kebenaran informasi yang diperoleh melalui media online kemudian mengecek ke sumber website perusahaan untuk mengantisipasi apakah informasi pekerjaan tersebut hoax. Mereka selektif, maksudnya, tidak mengirimkan lamaran sembarangan untuk menghindari penyalahgunaan data pribadi dalam surat lamaran pekerjaan. Untuk berbagi informasi dengan kerabat atau rekan kerja mereka banyak menggunakan media chat aplikasi whatsapp. Sementara itu, sarjana fresh graduate di daerah pedesaan masih menggunakan unsur silaturahmi. Hal ini menunjukkan bahwa keadaan demografis yang berbeda memiliki perilaku informasi yang berbeda pula, sehingga unsur demografis mempengaruhi perilaku pencarian informasi.

\section{Pengaruh Interpersonal Sarjana Freshgraduate dalam Mencari Informasi Pekerjaan}

Peran interpersonal individu turut mempengaruhi perilaku pencarian informasi (Wilson, 1999). Interpersonal yang digali peneliti meliputi kemampuan komunikasi, kemampuan membangun relationship, self 
esteem dan public speaking. Faktor personal seperti self-esteem juga turut mempengaruhi perilaku pencarian kerja yang dikaitkan dengan keterampilan sosial dan inisiatif individu (Amalina, 2016). Penelitian ini memperlihatkan bahwa individu dengan kemampuan komunikasi yang bagus dan mempunyai self esteem yang tinggi mempengaruhi perilaku pencarian kerja yang dikaitkan dengan keterampilan sosial dan inisiatif individu. Pada saat melakukan pencarian informasi, sarjana fresh graduate dengan self-esteem yang tinggi dan kemampuan komunikasi yang bagus menunjukkan keterampilan sosial yang kuat seperti aktif menanyakan informasi kepada seluruh kolega dan inisiatif mencari informasi pekerjaan dari berbagai sumber. Sementara itu, individu yang memiliki self-esteem rendah cenderung kurang percaya diri dan kurang aktif dalam melakukan pencarian informasi.

Suatu disiplin ilmu tidak mempengaruhi perilaku pencarian informasi (Korobili et al., 2011). Dari kesepuluh informan menempuh pendidikan 9 jurusan yang berbeda, hasil penelitian menunjukkan bahwa disiplin ilmu tidak mempengaruhi perilaku informasi. Namun ada faktor lain yang mempengaruhi perilaku informasi, yaitu reputasi kampus. Sarjana fresh graduate dari kampus-kampus yang bereputasi lebih tinggi, seperti Universitas Indonesia dan Universitas Padjajaran mempunyai self-esteem yang tinggi; sementara sarjana fresh graduate dengan reputasi di bawahnya, mempunyai self-esteem yang rendah yaitu merasa tidak yakin atas kemampuannya sendiri, merasa kalah saing dengan kampus ternama hingga menyebabkan minder dan kurang percaya diri dalam melakukan pencarian informasi.

Kemampuan membangun relationship berhubungan dengan kemampuan public speaking dan mempengaruhi perilaku pencarian informasi. Hasil penelitian menunjukkan bahwa sarjana fresh graduate yang mampu membangun relationship dengan kolega dan dosen-dosennya terdahulu mempengaruhi cara mereka bertanya, bersikap, dan bertindak dalam mencari informasi. Sarjana fresh graduate yang pada saat kuliah menjadi aktivis mempunyai banyak kolega sehingga sumber informasi pekerjaan lebih luas dan tentunya pencarian informasinya adalah pencarian aktif. Demikian halnya dengan sarjana fresh graduate yang mempunyai kemampuan public speaking yang bagus, mereka aktif dalam melakukan pencarian informasi dan aktif melakukan pengecekan ulang terhadap sumber informasi yang sudah diperolehnya selain melalui website maupun melalui koleganya.

\section{Pengaruh Lingkungan Sarjana Freshgraduate dalam Mencari Informasi Pekerjaan}

Keadaan lingkungan sekitar individu turut mempengaruhi perilaku pencarian informasi. Mayoritas sarjana fresh graduate di daerah pedesaan memiliki pekerjaan sebagai petani dan wiraswasta, sedangkan di perkotaan mayoritas pekerjaan adalah pengusaha dan PNS. Hasil penelitian ini menunjukkan bahwa lingkungan tempat tinggal turut mempengaruhi perilaku pencarian informasi. Pada saat Ita mencari informasi pekerjaan melalui online dengan lokasi tempat kerja jauh dari tempat tinggalnya, sarjana fresh graduate dari keluarga sederhana yang tinggal di pedesaan, memikirkan bagaimana biaya ketika mau melamar, berapa banyak tahapan ujian yang harus dilalui, dan belum juga lolos. Akhirnya, dia harus melakukan pencarian informasi pekerjaan lain, begitu seterusnya sehingga hal itu menghambat penemuan informasi pekerjaan. Ada hubungan saling ketergantungan antara kontekstual yang lebih luas dari faktor lingkungan digital dan tingkat informasi pengguna dalam perilaku pencarian informasi (Vuong et al., 2019). Terkait dengan akses informasi dimana sinyal kurang kuat, saat melakukan pencarian infomasi secara online, mereka harus ke pusat kota atau mengunjungi warnet yang menyita banyak waktu atau membeli paket data yang tergolong mahal di kalangan mereka. Untuk mencari informasi secara offline, mereka juga harus mendatangi kota untuk membeli koran yang berisi lowongan pekerjaan. Jadi faktor lingkungan dalam perilaku informasi berhubungan juga dengan hambatan waktu dan ekonomi. 
Sebaliknya, lingkungan perkotaan mayoritas pekerjaan lingkungan sekitar adalah pengusaha dan PNS, informasi dapat diakses dengan cepat, sumber informasi lebih banyak, dan memiliki hambatan ekonomi tentunya lebih kecil. Masalah yang timbul justru sumber informasi pekerjaan yang berlimpah tersebut membuat bingung mau memilih yang mana hingga akhirnya harus dilakukan seleksi yang memerlukan banyak waktu. Jadi selain faktor lingkungan perilaku informasi, juga ditemukan hambatan waktu penemuan informasi. Untuk menghadapi hambatan ini mereka melakukan berbagi informasi dengan rekan dan kerabat yang memiliki informasi yang lebih sesuai.

\section{Pengaruh Karaketristik Sumber Informasi Pekerjaan}

Wilson (1999) mengatakan bahwa karakteristik sumber informasi turut mempengaruhi perilaku pencarian informasi. Karakteristik sumber informasi pekerjaan yang digali peneliti meliputi media online dan offline, yaitu berupa media cetak dan lisan. Sarjana fresh graduate yang sudah terbiasa memanfaatkan media online (sebagian besar dari hasil penelitian informan yang tinggal di perkotaan) lebih cepat mengakses informasi pekerjaan dan mempunyai kemampuan lebih dalam menyaring sumber informasi yang mereka peroleh. Masalah yang kemudian muncul adalah berlimpahnya informasi yang mengandung unsur hoax dan pemanfaatan data pribadi. Oleh karena itu mereka merujuk ke website asal perusahaan yang membuka lowongan, mengcrosscek apakah sumber informasi tersebut akurat dan terpercaya serta memastikan kualitas informasi yang mereka peroleh.

Berdasarkan penuturan Tuti, Jihan, Anik dan Ratih, mereka masih menggunakan cara offline seperti media cetak dan lisan. Untuk media lisan, mereka mengcrosscek kebenaran informasi kepada rekan atau kolega pemberi informasi dan mendatangi langsung instansi pembuka lowongan pekerjaan. Dalam media cetak, yaitu lowongan di surat kabar, beberapa informasi pekerjaan tidak lengkap dan bahkan kadang memunculkan nomor hp dan setelah ditelusuri informan, ternyata pekerjaan yang dimaksud adalah semacam MLM. Selain itu beberapa informasi pekerjaan tidak langsung mencantumkan alamat dan kontak sehingga menghambat proses penemuan informasi. Dengan kredibilitas dan kualitas informasi pekerjaan yang rendah, sarjana fresh graduate harus teliti dan harus melakukan berulangkali pencarian informasi-apabila informasi yang ditemukan belum sesuai.

Pengaruh karakteristik informasi dalam pencarian informasi ini mempengaruhi perilaku pencarian informasi. Karakteristik keakuratan, kredibilitas, dan kualitas sumber informasi yang tinggi menunjukkan keberhasilan pencarian informasi dan nilai guna informasi tersebut tinggi. Begitu pun sebaliknya, karakteristik keakuratan, kredibilitas dan kualitas sumber informasi yang rendah mengakibatkan hambatan dalam penemuan informasi. Tiga dari sepuluh informan menyatakan bahwa keberhasilan dalam pencarian informasi pekerjaan mencapai $80 \%$, sedangkan selebihnya ada yang masih belum puas dengan hasil pencarian informasi pekerjaan, bahkan satu diantaranya belum menemukan informasi pekerjaan sama sekali.

\section{E. KESIMPULAN}

Kesimpulan penelitian ini menunjukkan bahwa perilaku pencarian informasi pekerjaan oleh 10 sarjana fresh graduate dikonstruksi oleh demografi, kemampuan interpersonal, dan lingkungan. Ketiga faktor dari lima variable intervening dalam konsep Wilson saling berhubungan dan membentuk pola yang berbeda berdasarkan kondisi lingkungan. 5 sarjana fresh graduate yang berasal dari daerah perkotaan dengan kemudahan akses internet untuk menemukan sumber informasi yang lebih luas, ditambah dengan kemampuan berkomunikasi dan sebagai aktivis ketika kuliah, mereka menerapkan pola pencarian informasi aktif. Sebagai lulusan perguruan tinggi yang ternama, dan dengan percaya diri yang tinggi, mereka menyeleksi informasi pekerjaan yang benar-benar sesuai dengan keahlian mereka. Sementara itu, 5 sarjana fresh graduate yang berasal dari pedesaan, memiliki 
pola pencarian informasi dengan perhatian pasif. Lingkungan dengan struktur sosial di pedesaan yang mengandalkan hubungan sosial yang lebih erat, memungkinkan mereka untuk menjadikan proses pencarian informasi kepada kerabat dekat ini sebagai ruang untuk bersilaturahmi. Pencarian informasi dengan perhatian pasif dibangun oleh adanya keyakinan bahwa seorang sarjana akan memperoleh pekerjaan yang baik dan diharapkan dapat menjadi kaya. Keyakinan tersebut menjadi tekanan psikologis bagi mereka, sehingga mereka menerima pekerjaan apa pun, tanpa menyeleksi kesesuaian pekerjaan dengan keahlian.

Saran yang direkomendasikan untuk penelitian selanjutnya adalah memfokuskan penelitian pada pencarian informasi pekerjaan oleh sarjana fresh graduate berdasarkan demografi, khususnya di pedesaan atau daerah rural. Dengan keterbatasan lingkungan tersebut, menarik untuk diteliti upaya yang mereka lakukan untuk mengatasi hambatan.

\section{DAFTAR PUSTAKA}

Al-Samarraie, H., Eldenfria, A., \& Dawoud, H. (2017). The impact of personality traits on users' information-seeking behavior. Information Processing and Management, 53(1), 237-247. https://doi.org/10.1016/ j.ipm.2016.08.004

Amalina, F. (2016). Pengaruh self-esteem dan job search self-efficacy terhadap perilaku pencarian kerja pada sarjana baru (Thesis Universitas Indonesia). Retrieved from http://www.lontar.ui.ac.id/detail?id=20430 079\&lokasi=lokal

Badan Pusat Statistik. (2019). Rilis Berita Resmi Statistik. In Berita Resmi Statistik. Retrieved from https://www.bps.go.id/ press-release/2019/05/06/234/beritaresmi-statistik.html

Case, D. O. (2016). Looking for information : a survey of research on information seeking (4th Edition). UK: Emerald Group Publishing
Dinia, A. (2016). Hubungan trait conscientiousness dan perilaku pencarian kerja pada sarjana baru perguruan tinggi (Thesis Universitas Indonesia). Retrieved from http://lib.ui.ac.id/detail?id= 20430333\&lokasi=lokal

Fetherston, M. (2017). College students and career information seeking: applying the comprehensive model of information seeking to career Preparation (Thesis Dissertation The University of WisconsinMilwaukee). Retrieved from https://login.pallas2.tcl.sc.edu/login?url=h ttps://search.proquest.com/docview/19093 28769? accountid=13965\%0Ahttp://resolv er.ebscohost.com/openurl?ctx_ver $=$ Z39.88 $-2004 \& \operatorname{ctx}$ enc $=$ info: ofi/enc:UTF8\&rfr_id=info:sid/ProQuest + Dissertations $+\% 26+$ Theses + Global\&rft v

Gordon, I. D., Meindl, P., White, M., \& Szigeti, K. (2018). Information seeking behaviors, attitudes, and choices of academic chemists. Science and Technology Libraries, 37(2), 130-151. https://doi.org/ 10.1080/0194262X.2018.1445063

Korobili, S., Malliari, A., \& Zapounidou, S. (2011). Factors that influence informationseeking behavior: the case of Greek Graduate Students. Journal of Academic Librarianship, 37(2), 155-165. https://doi.org/10.1016/j.acalib.2011.02.00 8

Laksmi, K. F. (2016). Budaya informasi. Jakarta: ISIPII Press.

Lueg, C. P. (2015). The missing link: information behavior research and its estranged relationship with embodiment. Journal of the Association for Information Science and Technology, 66(12), 2704-2707. https://doi.org/10.1002/asi. 23441

Miles, M.B, Huberman, A.M, \& Saldana, J. (2014). Qualitative data analysis, A. Methods sourcebook, Edition 3. USA: Sage Publications 
Mitsui, M., Shah, C., \& Belkin, N. J. (2016). Extracting information seeking intentions for web search sessions. SIGIR 2016 Proceedings of the 39th International ACM SIGIR Conference on Research and Development in Information Retrieval, 841-844. https://doi.org/10.1145/ 2911451.2914746

Moleong, L. (2017). Metodologi penelitian kualitatif. Bandung: Remaja Rosdakarya.

Mowbray, J., Hall, H., Raeside, R., \& Robertson, P. J. (2018). Job search information behaviours: An ego-net study of networking amongst young job-seekers. Journal of Librarianship and Information Science, 50(3), 239-253. https://doi.org/ $10.1177 / 0961000618769965$

Orso, V., Ruotsalo, T., Leino, J., Gamberini, L., \& Jacucci, G. (2017). Overlaying social information: The effects on users' search and information-selection behavior. Information Processing and Management, 53(6), 1269-1286. https://doi.org/ 10.1016/j.ipm.2017.06.001

Susilo, R. D.. (2018). Perilaku penemuan informasi lulusan fresh graduate FISIP Universitas Airlangga dalam proses pencarian pekerjaan (Thesis Universitas Surabaya). Retrieved from http://repository.unair.ac.id/74748/

Savolainen, R. (2018). Self-determination and expectancy-value: Comparison of cognitive psychological approaches to motivators for information seeking about job opportunities. Aslib Journal of Information Management, 70(1), 123-140. https://doi.org/10.1108/AJIM-10-20170242
Sugiyono. (2016). Metode penelitian kuantitatif, kualitatif dan $R \& D$. Bandung: Alfabeta.

Titus, T. (2016). Generation Y: Using social media for job searching? An exploratory study of how Generation Y job seekers use social media to fulfil their job searching needs (Masters Thesis Dublin, National College of Ireland). Retrieved from http://trap.ncirl.ie/2336/

Van Hoye, G. (2017). Job-search behavior as a multidimensional construct: A review of different job-search behaviors and sources. In The Oxford Handbook of Job Loss and Job Search. https://doi.org/10.1093/ oxfordhb/9780199764921.013.009

Vuong, T., Saastamoinen, M., Jacucci, G., \& Ruotsalo, T. (2019). Understanding user behavior in naturalistic information search tasks. Journal of the Association for Information Science and Technology, 70(11), 1248-1261. https://doi.org/ 10.1002/asi.24201

Widiyastuti. (2016). Perbandingan teori pelaku pencarian informasi menurut Ellis, Wilson dan Kuhlthau. Information Sains, 3(2), 51-64. Retrieved from https://ejurnal.unilak.ac.id/index.php/pb/ar ticle/view/281

Wilson, T. D. (1984). The cognitive approach to information-seeking behaviour and information use. Social Science Information Studies, 4(2-3), 197-204. https://doi.org/10.1016/0143-6236(84) 90076-0

Wilson, T. D. (1999). Models in information behaviour research. Journal of Documentation, 55(3), 249-270. https://doi.org/10.1108/EUM00000000071 45 


\section{DAFTAR GAMBAR}

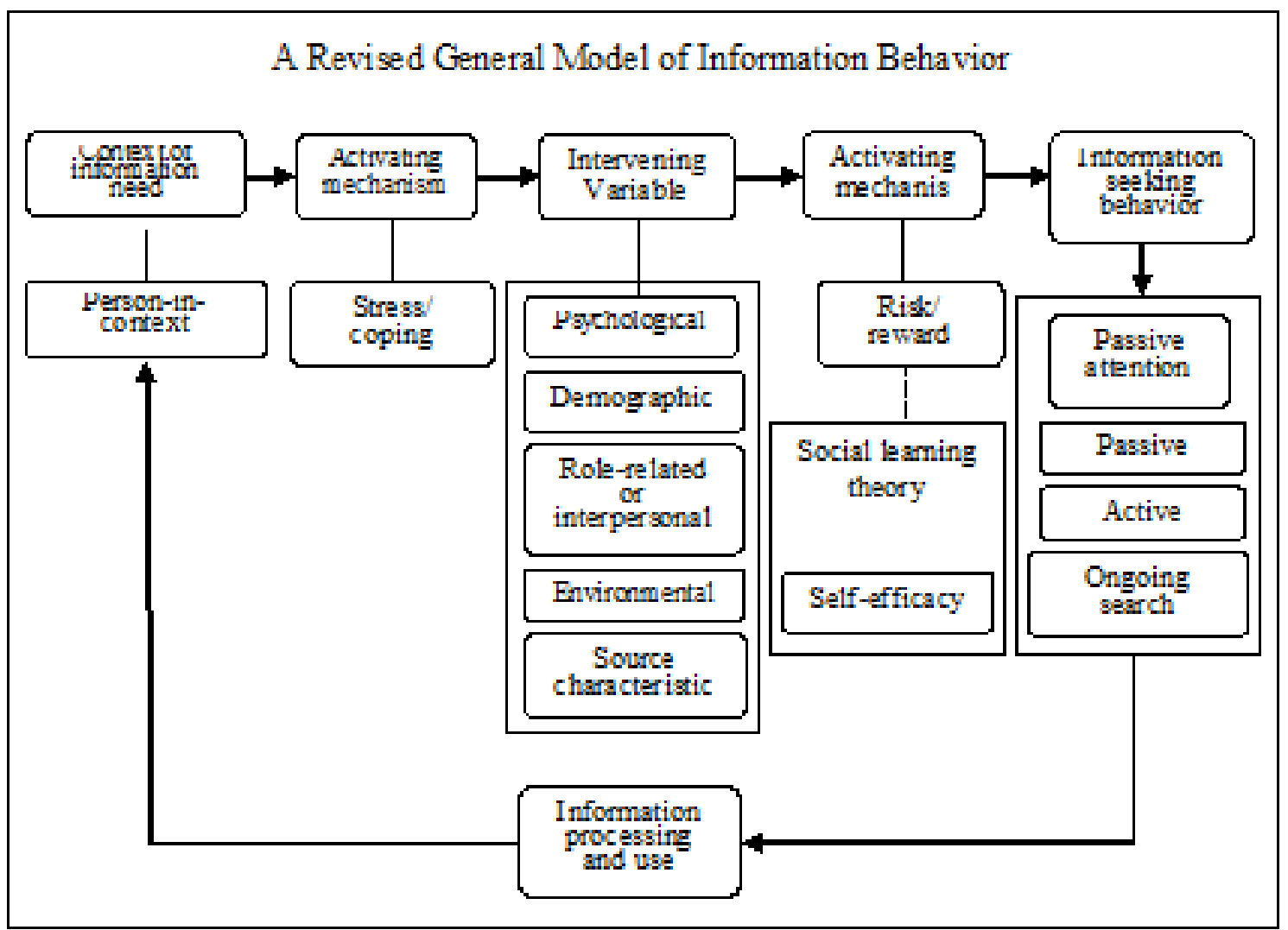

Gambar 1. Model Perilaku Informasi Wilson, Sumber: Wilson (1991)

\section{DAFTAR TABEL}

Tabel 1. Data umum informan

\begin{tabular}{lllllll}
\hline No & $\begin{array}{c}\text { Nama } \\
\text { Samaran }\end{array}$ & Usia & Alamat & \multicolumn{1}{c}{ Pendidikan } & \multicolumn{1}{c}{$\begin{array}{c}\text { Asal Perguruan } \\
\text { Tinggi }\end{array}$} & $\begin{array}{c}\text { Tempat } \\
\text { Tinggal }\end{array}$ \\
\hline 1 & Wati & 23 & Tangerang & Sastra Jawa & Universitas Negeri Sebelas Maret & Kota \\
2 & Tuti & 23 & Ngawi & Pend. Matematika & Universitas Negeri Malang & Desa \\
3 & Ita & 23 & Sleman & Kesejahteraan Sosial & UIN Sunan Kalijaga & Desa \\
4 & Jihan & 21 & Pati & Pendidikan PAUD & UIN Sunan Kalijaga & Desa \\
5 & Anik & 22 & Bantul & Pendidikan Bahasa & Universitas Ahmad Dahlan & Desa \\
6 & Ratih & 23 & Jambi & Seni Drama & Universitas Jambi & Desa \\
7 & Desi & 23 & Bogor & Ilmu Perpustakaan & Universitas Padjajajaran & Kota \\
8 & Anto & 23 & Solo & Ilmu Komunikasi & UIN Sunan Kalijaga & Kota \\
9 & Karto & 23 & Jakarta & Ilmu Perpustakaan & Universitas Padjajajaran & Kota \\
10 & Ipul & 23 & Bekasi & Informasi & Universitas Indonesia & Kota \\
\hline
\end{tabular}

Sumber : Data primer yang diolah, 2019 